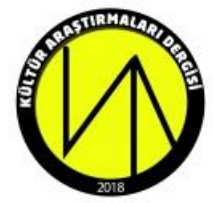

\title{
YAŞAR KEMAL'IN ROMANLARINDA DEFIN RITÜELLERININ SOSYAL-KÜLTÜREL TEMELLERi
}

The Social-Cultural Foundations of the Burial Rituals in Yasar Kemal's Novels

\section{Aziz ŞEKER*}

\section{ÖZET}

Yaşar Kemal, Türk ve dünya edebiyatının önemli romancıları arasında yer alır. Anadolu toplumlarının sözlü anlatılarını çağdaş roman kurgusu içinde yeniden üreterek, evrensel bir düzeye taşıyan Yaşar Kemal'in başarısı, bu toplumların kolektif belleğinde yer etmiş ritüelleri gerçekçi bir biçimde sosyal-kültürel temelleriyle ele almasından ileri gelir. Aynı zamanda Yaşar Kemal, insanları derinden etkileyen birçok toplumsal olguyu roman kurgusu içerisinde estetize etmiştir. Bunu yaparken oluşturduğu roman kahramanları aracılığıyla ekolojik bir döngüde var olan toplumsal gerçekliği de yansıtır. Bütün bu özellikler Yaşar Kemal'in romanlarına sosyolojik ve antropolojik bir bakış açısıyla eğilmeyi beraberinde getirir. Dolayısıyla genel olarak bakıldığında onun romanlarında insanlara, farklı kültürlere, topluluklara dair çıkarımlar yapmak mümkündür. Bu çalışmada Yaşar Kemal'in romanlarında, özellikle Çukurova bölgesindeki Türkmen aşiretlerinde defin ritüellerinin insani boyutu değerlendirilirken, bu merasimlerde ağıt yakma başta olmak üzere yerine getirilen bazı pratiklerin önemi ve işlevi irdelenmiştir. Çalışma bu yönüyle Anadolu Türkmen kültüründe defin ritüellerinin ve ağıtların sosyal kültürel temellerini ortaya çıkarması açısından veriler içermektedir.

Anahtar Sözcükler: Yaşar Kemal, roman, Türkmenler, ağıt, antropoloji.

\section{ABSTRACT}

Yasar Kemal is among the important novelists of Turkish and world literature. The success of Yasar Kemal, who reproduced the oral narratives of Anatolian societies in contemporary novel fiction and carried these narratives to a universal level, originates from the fact that the rituals in the collective memory of these societies are handled in a realist way with their social-cultural foundations. At the same time Yasar Kemal has aestheted many social phenomena in the form of novel fiction. He reflects social reality which embedded in ecological cycle through novel heroes when he writes his novels. All these features leads to sociological and anthropological points of view to Yasar Kemal's novels. Therefore, in the gen-

\footnotetext{
* Dr., Amasya Üniversitesi, Rektörlük Birimi, Amasya/Türkiye. E-posta: shuaziz@gmail.com. ORCID ID: 0000-0001-5634-0221. 
eral sense, the inferences about different culture, societies and human beings can be got from his novels. In this study, the human dimension of the burial customs of the Turkmen tribes in Yaşar Kemal's novels, especially in Cukurova region, will be evaluated and the importance and function of some practices in these rituals, especially lamenting, will be examined. In this respect, the study includes data revealing the social cultural foundations of burial rituals and laments in the Anatolian Turkmen culture.

Keywords: Yasar Kemal, novel, Turkmens, lament, anthropology.

\section{Giriş}

Bütün sözlü ve yazılı anlatıların gösterdiği gibi, ölüm sadece bir doğal olay değil; bundan daha fazlası olarak aynı zamanda kültürel hayatın inşasında etkili olan çok temel önemde bir toplumsal olaydır. Ölen bedenlerden çok yaşayanların sürdürmekte oldukları hayat içerisinde anlam yükledikleri ve yeniden kurdukları bir toplumsal alandır. Dolayısıyla çeşitli kültürlerde ölüm hallerinin nasıl anlamlandırıldığı ve algılandığı kendi toplumsal/kültürel koşulları ve özgün yapısı içerisinde ele alınmaktadır (Aslan, 2017: 249). Bir biyo-kültür olayı kabul edilen ölü gömme geleneği ise insanlık tarihi içinde uzun bir geçmişe sahiptir. Ölen bedenler için cenaze törenlerinin düzenlenmesi ve ölünün törenle anılmasının evrensel, tarih ve kültürler üstü boyutta olması, karşılaştırmalı etnografinin en eski ve en çarpıcı buluşlarından biridir. Yeni ölmüş bedenlere ve bu bedenlerin yakınlarının belleklerindeki ölümden sonraki varlıklarına yaklaşım konusunda bir modele uymayan, ne kadar basit olursa olsun hiçbir insani yaşam biçimiyle karşılaşılmamıştır (Bauman, 2012: 70). Örneğin insanlık tarihinde orta paleolitik dönemde yani Neandertal insanının yaşadığı zamanlarda Neandertal mezarlarıla ilgili Karmel Dağı ve Skhul mağaralarında bulunanlara yönelik yapılan değerlendirmelerde ölü gömme töresinin bu çağda oldukça yaygıın bir gelenek haline geldiği belirtilir. Bazı mezarlarda, cesedin yanında -kabrin içine konmuş- aletler bulunmuştur. Bulgular, ölüm olgusunun, orta paleolitikte yaşayan insanlarca "uzak bir diyara doğru yolculuk" ya da "ölümsüzlük" gibi algılandığı şeklinde yorumlanmıştır (Güvenç, 1991: 157).

Antropolog Hocart ilkellerin ölüm korkusundan sıkıntı duymadıklarını; antropolojik olgunun basiretli bir tecrübesinin, ölümün genellikle büyük sevinç ve şenliklerle karşılandığını gösterdiğini; irlanda'daki ölü bekleme geleneği gibi ölümün korkudan çok bir kutlama vesilesi gibi göründüğünü ileri sürmüştür. ilkeller genellikle Hocart ve başkalarının iddia ettiği gibi ölümü kutlarlar, çünkü onlar, ölümün nihai bir gelişme, daha üstün bir 
hayat biçimine, sonsuzluğa ulaşmaya, son yükseliş ritüeli olduğuna inanırlar (Becker, 2013: 19-20). Bu noktada paradoksal olarak, ölüm de yaşama anlam vermek için temel bir arzunun kaynağı şeklinde kabul edilmektedir. Öyle ki, ölümlülük ve sınırlılı̆ın bilgisi, kendi yaşamlarına anlam katma iddiasıyla insanlara bir dizi fırsatlar sunan insan kültürüne katılımda, temel bir güdü ve neden olarak görülürken kültürel görecelik bağlamında kültürden kültüre farklılık sergileyebilmektedir (Seale, 2012: 448).

Eski Türk halklarında da ölen bedenlere yönelik defin ritüelleri yerine getirildiği bilinmektedir. Ritüeller içinde ağırlıklı yer kaplayan ağıt, ölümden hemen sonra başlayan ölü gömme sürecinin başlangıç noktası olarak değerlendirilir. Ağıt yakma, merasimle yapılan taşımaya kadar sürer ve gömme sırasında yenilenir. Yalnızca acının ve yaşanan ikilemin doğal bir ifadesi değil, aynı zamanda bir görevdir. Yakutların, Kumandinlerin, Tuvalıların ve Tofaların ölü evde bulunduğu sürece ağıt yaktıkları tespit edilmiştir. Tuvalı şamanlarda ağıt, ölümün gerçekleşmesiyle başlar ve ölünün çadırdan çıkarılmasına kadar aralıklarla devam eder. Kadınlar ölüye ağıt yakarlar. Ağıtlara inlemeler ve türküler karışır, ölünün dışarı taşınmasına doğru ağıtların ses tonu yükselir (Tryjarski, 2012: 158-159). Kumandinli kadınlar ölü tabuta konulur konulmaz yakınmalara başlarlar. Avuç içleri birbirine değecek şekilde ellerini tabutun üzerine koyarlar, yüzleri yukarıya kalkık bir halde tabuta doğru eğilerek feryat ederler (Alekseev 1980'den akt. Tryjarski, 2012: 161).

Ölü gömme sürecinde ağıt yakılması geleneğinin çok uzun bir kültürel geçmişi bulunduğu üzerinde geniş bir uzlaşı vardır. Öte yandan ölüme yönelik kültürel ve geleneksel tutumun karşıı̆ı ağıtları bile aşan bir kabullenişle karşımıza çıkmaktadır. Bu tutumları Freud şöyle açıklamıştır:

Ölen gerçek kişiye karşı özel bir tutum benimseriz: neredeyse, çok zor bir işi başaran birisine duyulan hayranlık gibi bir şey. Ona yönelik eleştirilerimizi askıya alır, olabilecek yanlışlarını görmezden gelir, ölüde iyiden başka bir şey, olmadığını söyler ve cenaze töreninde ve mezarı başında anısına en güzel şeyleri söyleme gereği duyarız. Artık intiyaç duymayan ölüye saygı, bizim için, gerçeğe ve elbette çoğumuz için yaşayana saygıdan çok daha önemlidir (Freud, 1995: 76).

\section{Edebi Metinlerde Defin Ritüellerinin Sosyolojik Çözümlemesi}

Edebi metinlerde ölü gömme törenlerinde en belirleyici ögeler arasında kabul edilen ağıt yakmak en sık rastlanan ritüellerden biridir. M.Ö. 5000-4000'li yıllara kadar giden ağıt yakmanın ilk yazılı kaynaklara sahip Sümerlere dayandığına dair kaynaklar bulunmaktadır. Binlerce yıl sonraya 
gelen tabletlerdeki Sümer yazıları çözümlenerek bu konu da gün yüzüne çıkarılmıştır. Bunu somutlaştırmak adına Sümer ülkesine ait Gılgamış Des tanı'na bakmak gerekir. Destanda Gılgamış ile Enkidu, sedir ağaçlarından yararlanmak için, ormanı koruyan Humbaba ile Gök Boğa'sını öldürürler. Bunun üzerine tanrılar Enkidu'yu ölüme mahkûm ederler. Ölümünden sonra Uruklular ağıt yakarlar ve yas tutarlar. Enkidu'nun ölümüyle dostu Gılgamış, kentin uluları önünde, arkadaşı için uzun bir ağıt yakar, onun üstün niteliklerini sayıp döker. Kentin kuyumcularını çağırarak onun doğal büyüklükte, altın bir yontusunu yaptırır. Destanın yazılı olduğu tablette ağıt yakılma anı şöyle betimlenir: "Utkularımızı bilen kentliler ağlasın sana; ağlasın sana tarlaları kurtulmuş çiftçi, gönül borcunu şarkıyla dile getiren, adını yücelten çiftçi... Uruklulara ağıt yaktırdım, gözyaşı döktürdüm, mutlu kullarımı yasa büründürdüm senin için, senin ölümünden sonra saçlarım kirli geziyorum, bir aslan postuna sarındım çöllerde dolaşmak için başıboş." (Maden, 2018: 77, 80-82).

Başka bir açıdan bakıldığında çok eski zamanlardan beri hem ölüm karşısında öznel bir kabullenişin acısını yansıtırcasına hem de ölünün gömülme sürecinde sosyal kültürel bir ritüeli sürdürmek adına ölünün yakınları, cenaze merasimine katılanlar ve daha çok kadınlar onun kaybı nedeniyle ağlarlar. Ağıt yakarlar. Ağlarken, iç çekerken, sızlanırken ve bağııırken onun meziyetlerini ve eylemlerini hatırlarlar. Ölümün gerçekleşmesinden hemen sonra başlayan ağlaşmalar törenle taşımaya ve gömme sırasında ve oldukça uzun yas süresince ölü için yapılan merasimlerde devam eder (Tryjarski, 2012: 252). Buna ilişkin olarak sosyal kültürel yönlerden yaklaşıldığında insanlığın tarihinde birçok deneyimle karşılaşılmaktadır. Örneğin Homeros'un ilyada'sı Troyalılar ile Akhalar arasında yıllarca süren savaşı konu alır. Troyalı Hektor, Akhilleus'un yakın arkadaşı Patroklos'u öldürdüğünde, denizin dibinden çıkan Nereus kızları ağıt yakarlar. Aynı şekilde arkadaşının öcünü almak amacıyla Hektor'un Akhilleus tarafından öldürülmesi sonrasında ağıtlar yakılır. Anne Hekabe'nin ağıt yakmasıyla ilgili Homeros şöyle bir giriş yapar:

Bak anana yavrum, talihsiz anana, senin acını göreyim, öldüğünü göreyim de, bundan böyle nasıl yaşayayım ben, nasıl? Gece gündüz yüreğimin ışığıydın bu kentte, Troyalı kadınların, erkeklerin gücü desteği, bir tanrı gibi selamlardı yavrum onlar seni, sen onların büyük şanıydın sağken, ama yavrum, kaderle ölümün elindesin şimdi (Homeros, 2019: 433-435).

Patroklos ve Hektor için her iki taraf cenaze merasimi düzenlerler. Ölüler yakılır. Ölünün bedenine etrafta bulunan insanlar saçlarını kesip 
atarlar. Hektor'un cenaze merasiminde ozanlar ve daha çok kadınlar ağıt yakarlar. Ateşe verilen beden söndükten sonra ağlaşmalar eşliğinde kemikler toplanıp bir tümsek mezar yapılır. Sonrasında şölen yemeği düzenlenir. Homeros'un Odysseia isimli eserindeyse ölen Akhilleus için yapılan cenaze töreni anımsatılır. Atreusoğlu Ölüler Ülkesi'nde Akhilleus adına yapılan ölü törenini anlatır. Törenden sonra Akhilleus'un kemikleri toplanıp bir höyük oluşturulur:

Dokuz Musa da karşılıklı ağıtlar okudular güzel sesleriyle, öyle dokunaklı çıkıyordu ki ağızlarından o ağıtlar, kalmadı gözyaşı dökmeyen tek bir Akhalı. İşte böyle ağladık on yedi gün, on yedi gece, ölümlü insanlar ve ölümsüz tanrılar ağladık sana. Verdik seni ateşe on sekizinci günü, kurban ettik çevrende semiz koyunlar, paytak yürüyen inekler. Yakıldın tanrısal giysiler, kokulu yağlar, tatlı ballar içinde, yanan ateş yığınının çevresinde dört döndüler birçok silahlı Akha yiğitleri, yaya ve arabalarla, yükseldi gürültüler gökyüzüne kadar (Homeros, 2003: 361-362).

M.Ö. 9. yüzyılda yaşamış Homeros'un destanlarındaki anlatımından Troya'daki toplumsal hayat çok çeşitli ögeleriyle analiz edilebilmektedir. Eski toplumlarda rastlanan defin geleneklerinde gerçekleştirilen pratikler kültürel mirasa kaynaklık etmekle birlikte, defin ritüellerinin görevi ölüm tarafından temsil edilen kini ve tehlikeyi daha pozitif ve güvenli bir şeye dönüştürmektir. Psikososyal açıdan eğer ölüm, yaşamı koruyan ve destekleyen iyiliksever bir ruh olarak anlaşılırsa, bizzat ölümün kendisi potansiyel olarak az korkulan ve daha az yıkıcı bir şey olmaktadır (Seale, 2012: 451).

Genel hatlarıyla bakıldığında, kadim dinlerde ve inanç sistemlerinde bulunan, yaşamın ölümden sonra sürdürüldüğü düşüncesiyle paralel (Can, 2015: 177), sosyal, kültürel dini pratiklerde ve ritüellerde ölünün ardından ortaya çıkan soru işaretlerinin büyük olasılıkla evrensel olduğu aşikârdır. Çünkü geride kalanların içlerini rahatlatabilmeleri için ölüye sembolik ve belki de dini bir tören yapılması şartı ile hayatın ve toplumun ölünün ardından da değişmez bir şekilde var olmaya devam ettiği düşüncesi güçlü bir yön verici olmaktadır (Eriksen, 2019: 225).

Edebi metinlerde yer bulmuş defin ritüellerinde ağıt yakmayla ilgili olarak Yaşar Kemal'in romanlarında da birçok kesit yer alır. Günümüzde ağıtın evrenselliğini ve sosyolojik temelini görmek adına yazarın romanlarına bakmakta fayda bulunmaktadır. Yaşar Kemal 1950-2000 yılları arasını kapsayan romanlarında, ekonomik yönüyle geç kalmış bir feodalizmi, birincil ilişkilerin hâkim olduğu aşiret aristokrasisini ve yoğun bir patriyarka ile düzenlenmiş merkezi iktidarın karşısında roman kahramanlarının, insan 
sevgisi ve özgürlüğü ekseninde varoluşunu anlatırken, bu evrenselliği Çukurova'nın özgül renkleriyle anlamlandırır. Feodal ataerkil toplumu birçok unsuruyla kaleme alan Yaşar Kemal'in romanlarında ölü gömme törenlerinin ve ağıt yakmanın sosyal-kültürel yanıyla işlendiğini söylemek mümkündür (Timur, 2002: 386).

Yaşar Kemal'in kurguladığı roman kahramanlarının karakterize olduğu toplumsal yapıda ölü gömme pratikleri ve ağıt yakma önemli bir ritüeldir. Yaşar Kemal'in hemen hemen yarım yüzyıla yayılan romanlarından hareketle denebilir ki, insanlık tarihindeki ölü gömme törenlerinde önemli bir sosyal işlevi olduğu kabul edilen ağıt yakmanın özellikle bugün geleneksel toplumlarda hâlâ uygulanıyor olması, onun geçmişten günümüze kalan çok güçlü bir geleneksel öğe olduğunun kanıtıdır. Öyle ki geleneksel toplumlar, ağıt yakmayı yaşamın bir parçası olarak hâlen uygularken, doğaçlama özelliğini korur. Diğer yandan ağıt yakmak modern toplumlarda veya toplumların modern kesimlerinde gittikçe terk edilmeye başlanmıştır. Bunda toplumda baskın inanç sisteminin bu tip uygulamaları dışlaması ve dinsel uygulamaların her geçen gün modern insan tarafından terk edilmesinin etkisi büyüktür. Fakat dışlama ve modernleşmeye rağmen, ağıt yakmanın ya da ağıt söylemenin toplumların gelişimi ve değişimi doğrultusunda, ölüm ve onun neticesinde insanın duyduğu acı hissi yaşandığı sürece var olmaya devam edeceği bir gerçektir (Tahtaişleyen, 2013: 12).

Aşağıda Yaşar Kemal'in romanlarında defin ritüelleri ile ağıt yakma olgusu sosyal kültürel temeliyle beraber ele alınırken, söz konusu durumların geçtiği romanlarla sınırlı nitel bir çözümleme yapılmıştır.

\section{Yaşar Kemal'in Romanlarında Defin Ritüellerinin Sosyal-Kültürel Temeli ve Ağıt}

Geniş çapta etnografik ve tarihsel kanıttan yola çıkan Bendann'ın klasik kültürlerarası araştırması şaşırtıcı bir ölüm geleneği yelpazesi sunmaktadır. Bunlar arasında cenaze törenleri, yas ayinleri, cenaze yemekleri, anma, adak, ölünün ölümden sonra varoluşuna ilişkin açık ya da örtük inançları davranış yoluyla dışavurma biçimleri en belirgin olanlarıdır (Bendann 1969'dan akt. Bauman, 2012: 70). Ölümün üzüntü ve acıyla karşılanmasını istemek, insanın doğasının gereğidir. Ancak defin pratikleri çok daha karmaşık kültürel ve sosyal süreçler içerir (Durkheim, 2010: 543). Cenaze törenlerinde ölenin onuruna yakılan ağıtlarla ilgili anlık ve törensel yakınmaların Türk halk sanatının özel bir türünün başlangıcı olduğu kabul edilmektedir. Bu tür, 8.yüzyıla ait olan en eski Türk metinlerinde "ir, yiir" tanımlarıyla kaydedilmiştir, ancak bu tanım ya da ifade, daha genel 
bir anlam ile "şarkı", sonraki zamanlarda varlığını sürdürmüştür. (Örneğin Osmanlıca “yır”, Kazakça “ğir”, Kıpçakça “jir”, "jer” vb. ). Eski Uygur edebiyatında uygun eşanlamlı kelime "taysur"dur ve bazı diğer Türk dillerinde uygun bir karşılık bulunmamaktadır. Sadece isimler değil, ağıtların tamamı uzun ömürlü olmuştur. Bunlar Anadolu'da ve Azerbaycan'da "ayit" adıyla anılmaktadır (Tryjarski, 2012: 252).

Ağıt sözlü kültürün ve sözlü edebiyatın önemli bir parçasıdır. Müzikal bakımdan ise sözlü müzik alanına dâhildir. Bu özelliği sebebiyle ağıtları müzik ürünü olarak incelerken edebiyattan bağımsız ele almamız olanaksızdır. Türkiye'de bugüne kadar yapılmış ağıt ile ilgili çalışmaların çoğu onun edebi özellikleri üzerinedir. Bu çalışmalar, Anadolu'nun çeşitli yörelerinden derlenen şeklen kusursuz Türkçe ağıt metinlerinin edebi özellikleri ve bu yörelerdeki yas törenleri hakkında verilen sosyolojik bilgileri kapsar. Edebiyat araştırmacılarının günümüze dek yapmış oldukları çalışmalar, ağıtların edebi formlarıyla ilgili detaylı bilgiler içermekle birlikte çoğunlukla bu veriler müzikten bağımsız olarak değerlendirilmişlerdir (Tahtaişleyen, 2017: 223).

Çağdaş edebiyatın evrensel figürleri arasında kabul edilen Yaşar Kemal, romanlarının sosyal-kültürel dokusunu oluşturan çevrelerde yaşanan cenaze merasimlerini ve ağıtları roman dünyasına taşıyarak, konuyla ilgilenenler için zengin bir materyal bırakmıştır. Yazarın incelenen romanlarında defin ritüelleri ile ağıt yakma geleneğinin estetik bir bütünlük içinde işlendiği görülmektedir. Romanlara eğilecek olursak, Yaşar Kemal'in Binboğalar Efsanesi'nde Karaçullu obasının en yaşlı adamı demirci Haydar Usta'dır. Giderek yoksullaşan, geleneklerinin bir kısmını yitiren Türkmen obasının kışlak ve yaylak sıkıntısı bulunmaktadır. Konacak bir yerleri kalmamıştır. Diğer pek çok Türkmen aşiretleri iskân edilmişlerdir. Türkmen obalarının toprağa yerleşmesiyle nakışlı kilimlerin, saray gibi kara çadırların eskimesi, güneşten solması ve çürümesi aynı zamanda geleneklerin, göreneklerin, kadim türkülerin, ağıtların yaşanan sıkıntılar içinde unutulup gittiğine işaret etmektedir (Kemal, 2001: 71). Yazarın, romanda Yörüklerin konargöçer olmasından kaynaklı olarak mezarlarına ilişkin verdiği şu ayrıntı, toplumsal bellekte yerini almıştır: "Yolda belde, kim nerede ölürse, öldüğü yere gömüverirler onu...” (Kemal, 2001: 60). Horasan'dan bu yana sürekli bir göç halinde bulunan Yörüklerin yaşamı dikkate değerdir. Örneğin Karaçullu obası gibi sorunlar yaşayan Horzumlu obasında, "Durancanın çocuğu bundan üç gün önce ölmüş, çocuğu bir yere gömecek kadar bir yerde mola verememişlerdi. Ölüyü üç günden beri anası sırtında taşıyordu" (Kemal, 2001: 120), göç bir yamaca konup çadırlar dikildikten sonra, 
çadırların önüne ateşler yakılıp, saçlarda yufka pişirilir. Bu esnada ölü gömme töreni yapılır: "Ekmekler pişirildikten sonra biraz su kaynattılar, kadınlar ölü çocuğu çabucak yıkadılar, Müslüm Koca bir kısacık dua okudu. Hep birden ölüyü götürüp kalenin surlarının dibine gömdüler. Çocuğun babası mezarın başucuna uzun bir çoban değneği dikip döndü" (Kemal, 2001: 121). Yazar başka bir çocuğun gömülme olayını ise şöyle vermektedir: "Karaçullu obasının çocukları sinekler gibi kırılıyordu. Bu sabah bir çocuğu daha Payas kalesinin dibine gömdüler, üstüne birkaç avuç Osmanlı toprağı attılar...” (Kemal, 2001: 149). Görülmektedir ki, YörüklerdeTürkmenlerde koşullara bağlı olarak cenaze çok basit bir törenle kaldırılır. Genellikle defin yerleri bu pastoral halkın, mabet için yeterli bulduğu kutsal ağaçların çevresindedir. Naaş bu mabet alanına götürülür ve Kuran'dan bir bölüm okunduktan sonra toprağa teslim edilir. Kutsal ağacın altındaki yığından alınıp mezara konan birkaç taş Yörük mevtayı hatırlatan tek izi oluşturur ve hiçbir biçimde kitabe dikilmez. Ayrıca ölünün, yoldan geçen dindarların dualarını alabilmesi için, defin yerleri her zaman bir patikanın yakınında seçilir (Garnett, 2009: 369). Obanın sorunlarını çözmek amacıyla yaptığı kılıcı yanına alarak yola çıkan Haydar Usta, önce Adana'ya gider. Ramazanoğlu Beyliği'nin ileri gelenlerini ziyaret etmeyi planlamaktadır. Ancak toplumsal değişim Adana'yı yenilemiş, bundan Ramazanoğlu dahi yararlanmasını bilmiştir. Ramazanoğlu fabrikalar kurmuş, milletvekilleri çıkarmış, zamanla bir sermaye gurubunun adı olmuştur. Haydar Usta, elinde bir umut gibi taşıdığı kılıcı verecek kimseyi bulamaz. Yüz çadırlı Karaçullu obasının yerleşeceği bir yer bulmak umuduyla bu kez Ankara'ya gitmeye karar verir. İsmet Paşa'yı görmeyi amaçlamaktadır. Horasan erlerinden Demirciler Ocağı piri Haydar Usta günlerce uğraşıp yaptığı kılıcı sunmak üzere gittiği Ankara'da, bir yolunu bulup ismet Paşa ile karşılaşır. Haydar Usta kılıcı verirken, Çukurova'da çektikleri sıkıntıları anlatır. Bir süre incelenen kılıç kendisine iade edilir. Obasına geri dönen Haydar Usta, sabaha kadar çadırında kılıcı yeniden döver. Sabah onu örsüne bitişik halde bulurlar. Köylülerin, Haydar Usta'nın ölüsüyle ilgili yaptığı defin işlemleri roman sayfalarına yansır:

Örsüyle birlikte topraktan söküp bir sala olduğu gibi koydular. Hemite dağının doruğuna tırmandılar. Ölüsünü Hamit Dedenin toprak mezarının yanına koyup, az ileriye, kesme ağacının dallarının ucunun geldiği yere, gündoğuya derin bir mezar kazdılar, bir adam boyunda. Haydar Ustayı olduğu gibi, örsüne sarılı mezara indirdiler. Balyozunu, öteki demircilik aletlerini yanına koydular. Üstüne ağır kokulu mersin çalısı dalı, yaprağı döşediler, toprakladılar. Yöresine taşlar dizdiler. Haydar 
Ustanın ölüsünü yumadılar. Ermişlerin ölüsü yunmak istemez. Ona ağıt yakmadılar, ağlamadılar, türkü söylemediler. Haydar Usta bunların hiçbirisini istemez. Ermiş kişiler bunların hiçbirisini istemezler (Kemal, 2001: 244).

Köylüler mezar yerinden döndükten sonra Haydar Usta'nın geride kalan, çadırını, giyitlerini, soykasını bir araya toplayıp ateşe atarlar. Göreneğe göre Haydar Usta'nın yaşlı atını, torunu Kerem'e öldürtürler. Haydar Usta'nın defin işlemi obanın son umutlarının yok oluşuyla anlam kazanır. Obalı onu bir ermiş statüsüne taşıyarak geleneklerine uygun bir pratikle toprağa verir. Geride kalan mezar yerinin, geleceğini kurmaya çalışan Yörük obasının karşılaştığı zorlukları ve acıları gidermek için umut olmaya kendini adayan Haydar Usta ile karakterize edilmesi, Yörüklerin o mezar yerine kültürel ve bir duygusal ilgiyle yaklaşmasını beraberinde getirecektir. Sosyolojik olarak bakıldığında kırsal/geleneksel kültürü içselleştirmiş insanlarda ölüm olayı, toplumsal dayanışmayı arttırmakta, grupsal ve toplumsal bütünleşmeyi belirli açılardan sağlamaktadır. Başka bir ifadeyle ölüm, toplumda var olan yapılanma, oluşum ve odaklanımların da yapısını değiştirmektedir (Kızılçelik, 2000: 136-138).

Yaşar Kemal'in Dağın Öte Yüzü üçlemesi (Ortadirek, Yer Demir Gök Bakır, Ölmez Otu), Yalak isminde bir Türkmen köyünde geçer. Yoksulluk içinde yaşayan köy halkı, kasaba tüccarı Adil'e olan borçları karşısında bir şey veremeyecekleri için kışı korku içinde geçirmektedirler. Adil'in köye gelme olasılığı sürerken köylü çaresizlik içinde beklemeye başlar. Köyde otoriteyi temsil eden, köylüye şiddet uygulamaktan çekinmeyen muhtar Sefer'in karşısına köylü tarafından doğru sözlü Taşbaş Memed çıkartılır. Köy halkı yoksulluk, kıtlık zamanlarında rastlandığı gibi umut ve güven gereksinimini bir bedende sembolleştirmek girişimini Taşbaş'। ermiş statüsüne taşıyarak yerine getirir. Köylülerin mit oluşturma çabası sonucunda Taşbaş Memed ne yaparsa yapsın ermiş olmadığını anlatamaz. Baş edemeyince bir ara kendisini ermişliğe kaptırır. Sonrasında muhtarın jurnallemesiyle karakola şikâyet edilir. Devrim kanunlarına karşı geldiği söylenerek götürüldüğü bir kış gecesi, tipi esnasında yolda jandarmadan kaçarak, izini kaybettirir. Taşbaş Memed serinin üçüncü cildi Ölmez Otu'nda köy halkına ve ailesine duyduğu özlemle ortaya çıkmaya karar verir. Çukurova'ya pamuk ırgatlığına inen köylülerin yanına gider. Kimse onunla ilgilenmez. Görmezden gelirler. Eşi bile "Taşbaş Efendimiz Kırklar dağında..." diyerek ondan uzak durmaya çalışır (Kemal, 2000a: 226). Onlara göre Taşbaş, Kırk Ölmezler arasına karışmıştır. Kendisi olduğunu köylüye inandıramaz. Köylüler onu ötekileştirir ve aşağılamaya kalkar. Bu davranışlarla 
baş edemeyeceğini anlayan Taşbaş, pamuk tarlasına yakın akan nehre bedenini bırakır. Köylülerin, "yerlerin göklerin ermişi Taşbaş Efendisi" ölmüştür (Kemal, 2000a: 328). Olayların gidiş hattına, ermiş miti yaratma ve ona inanma sosyal psikolojisinin dinamiklerine bakıldığında, kendisine ermiş rolü sunulması aslında köylü nazarında öldüğü gündür. Sıra Taşbaş'ın bir ermiş gibi gömülmesine gelir. Geride kalanların belleğinde ermiş miti, en kötü koşullarını yaşadıklarında ortaya çıkıp en azından sosyal sıkıntılarıyla baş edebilme direncini artırdığı için Taşbaş'ın bedeninin onurlu bir cenaze merasimiyle toprağa verilmesinden sonra da kültürel temelde yer almaya devam edecektir. Defin töreni başlarken Taşbaş'ın eşi ağıt yakar:

"Ermişim, evliyam, Kırklara karışmışım, karınları yemedi seni, çekemediler ermiş̧iğini, işte bu hale getirdiler seni..." Karısı üç kere üst üste bir çığlık daha attı, ölüye koştu, bırakmadılar. Sonunda sekiye çömeldi, güzel, dertli, yanık sesiyle bir ağıt tutturdu. "Ne yatarsın sevdiceğim, kuşluklayın ısıcakta," diyordu. "Seni bekliyorum, gene gel," diyordu. "Ne yatarsın sevdiceğim, kuşluklayın ısıcakta? Hazerine hüzerine, ışık yağmış mezarına, ne yatarsın kuşluklayın, gün altında ısıcakta, bin kır atın üzerine," diyordu. Birkaç kadın daha geldi katıldılar ağıt söyleyen kadına. Biri durup öteki söylüyor, biri durup biri söylüyordu (Kemal, 2000a: 328-330).

Defin esnasında Kel Âşık ölüyü yıkamaz istemez. Bilgece kurularak, iki elini göğsüne bastırdıktan sonra: "Bu ölü kefen istemez, üstünde giyitler var. Bizde de kefen yok. Duasını ben yaparım, namazını şimdi, şurada kılarız. Türbesini de şu karşı tepede yaparız. Zaten Taşbaşoğlu mezarında duracak değil. Bu gece Kırklar dağına çekilir gider. Bu ölü hiçbir şey istemez" der (Kemal, 2000a: 330). Kel Âşık imamlık yapar, cemaat arkasına sıralanarak namazı kıldıktan sonra olaylar şöyle gelişir:

Dört delikanlı ölüyü kaldırdılar, elleri üstüne aldılar, bir tabutu taşır gibi az ilerdeki etekleri yarpuz kokan tepeye götürdüler. Köylü tümüyle ölünün ardından tepeye kadar geldi. Ağır ağır, korkulu, yaslı. Bir anda mezarı kazdılar, köylüler yolda gelirlerken kucak kucak yarpuz toplamışlardı, küçücük mavi mineli çiçekler, mezara yarpuzları serdiler. Taşbaşı üstüne indirdiler... Ölünün gömüldüğü gün köylüler pamuk toplamadılar. Akşam ölü şöleni için yemekler pişirilir. Bütün yemekleri ikindi üstü Taşbaşın karısının alaçığına taşıdılar. Gün aşağı sarkarken sofralar kuruldu, kadınlar ayrı, erkekler ayrı, sofralara bağdaş kurup oturdular. Bir yemeğe başlamadan, bir de yemek bitince Taşbaşoğlunun ruhuna dualar okudu Kel Âşık. Yatsı ezanı bir dua daha okudu. 
Duaya herkes katıldı. Ve: "Allah sabırlar versin bacı," dediler Taşbaşın karısına. "Ölenle ölünmez. Allah rahmet eylesin, iyi adamdı, kimseye bir zararı dokunmadı," dediler. Teker teker, bu sözleri söyleyip oradan ayrildılar (Kemal, 2000a: 330, 331).

Yazar, Taşbaş'ın mezarını türbe biçiminde anlatıp, gömüldüğünün gecesinde milyonlarca ışıktan kuşun ışık seli gibi sabaha kadar türbenin bulunduğu tepeye döküldüğünü betimler. Böylece yazar, o yörede yaşayan insanlar ve Çukurova'ya pamuğa gelen köylüler için mezar yerinin ziyaret edilebilecek bir türbe olarak kabul edileceğini işaret eder.

Yaşar Kemal'in Akçasazın Ağaları serisinde yer alan Demirciler Çarşısı Cinayeti ile Yusufçuk Yusuf romanları; Akyollu Mustafa Bey ile Sarılar Aşiretinin Beyi Sarıoğlu Derviş Bey arasındaki kan davasının nedenlerine ve sonuçlarına odaklanırken, Çukurova toplum yapısını birçok yönüyle ele alır. Roman boyunca ölüm bir sarkaç gibi sayfalar arasında gezinir. Her ölü bir cenaze merasimiyle geleneklere göre onurlandırılır. Örneğin Derviş Bey'in adamlarından Mahmut, Mustafa Ağa'nın kardeşi Murtaza'yı öldürür. Cenazede Türkmen kadınları ak bir çarşafın altında uzanmış ölünün yaşamı üzerine ağıt yakarlar. Ağıtların dinmesiyle defin işlemine geçilir:

Mezarlığa gittiler. Balçık, tutkal gibi yapışkan, killi bir toprağı kazdılar. Mezar taşları küçücük, irice çakıl taşlarından... Hititlerden kalma bir hüyüğün yamacında. Bir tek, yarı gövdesi çürümüş bir dut ağacı da öylecene, yarısı kurumuş, yarısının yaprakları fidan yaprakları tazeliğinde. Balçık toprak, mezar taşları, yarısı çürük dut, Hitit hüyüğü, ötedeki kamışıık, adamların sırtları tütüyor. Her yandan mavi, kör edici bir bulut örneği buğu fışkırıyor. Ölüyü balçıktan kazdıkları tutkal gibi kil mezara indirdiler. Saldırmaları dayadılar. Saldırmalar yağlı çam ağacındandı. Saldırmaların üstüne murt çalıları yığdılar. Çalıların üstünü toprakladılar. Hoca kuran okudu. Adamlar orada ellerini kavuşturup beklediler. Burunlarında acı murt kokusu... (Kemal, 1998: 61).

Yusufçuk Yusuf'ta Mahmut yakalanır. Suçunu itiraf etmeyince karakolda gördüğü şiddet sonucu öldürülür. O da ağıtsız gönderilmez. Eşi Meyro başta olmak üzere diğer kadınlar Türkmen geleneğine göre Mahmud'un kanlı giyitlerini ortaya atıp, ölünün başında ölenin yiğitliği ve dostluğuna övücü ağıt yakarlar: "Kadınların ağıdı akşama kadar sürdü ve akşam yemeği için her evden Meyronun evine yemekler taşındı. Bu bütün köyün katıldığı büyük bir şölendi. Kadınlar ayrı, erkekler ayrı yerlerdi yemeği ama, sofralar bitişikçesine yan yana kurulurdu" (Kemal, 1999a: 111). Toplumsal gerçeği yansıtan romanlarda Anadolu'daki kadınlar, ağıt geleneğinin sürdürülmesinde sosyal işleve sahip karakterler olarak işlenmektedir. Ağıtın 
gerek icrasında ve gerekse törensel organizasyonunda kadınlar başroldedir. Toplumsal cinsiyet rollerinin Anadolu'daki yapılanma biçimi, kadının ağıt yoluyla kendine bir ifade ortamı bulmasına neden olmuştur. Sosyal hayatta ifade ortamı kısıtlı olan kadın, bu geleneğe sıkı sıkıya bağlanarak, üretimini ve uygulamalarını sürdürmüştür. Bu sebeple ağıt geleneğinin sürekliliği, büyük ölçüde kadın kimliğiyle sağlanmıştır (Tahtaişleyen, 2013: 133).

Yaşar Kemal'in magnum opusu kabul edilen ince Memed roman serisinin üçüncü cildinde, İnce Memed'in kasaba ağalarından Ali Safa Bey’i öldürmesinden sonra yapılan törende ağıtçı kadınlar yer bulmuştur:

Dün geceden bu yana, daha kurşun sesleri duyulur duyulmaz Ali Safa Beyin avlusu insanla dolmuştu. Kara haber en uzak köylere kadar ulaşmış, yakın köylerin ağıtçı kadınlarının bir kısmı çoktan gelmişler, işlerine başlamışlardı bile. Ali Safa Beyin kanlı ölüsü başında ağıtlarını söyleyerek ığranıyor, ölüyü göklere çıkarıyorlar, onun görkemli yaşamını, iyi niteliklerini, insanlığını sayıp döküyorlar, onu öldüren eli kanlı, yüreği kara ince Memedi de yerin dibine batırıyorlardı (Kemal, 2000b: 22).

Ölünün hemen gömülmesine ailesi razı gelmemiştir. Ölü kokmaya başlayınca ancak gömülme törenine geçilir. Öğle ezanına müteakip sala okunur:

Ali Safa Bey'in ölüsünü camiye kadar köylüleri, akrabaları zor taşımışlar, bir ikisi salacayı taşırken bayılıp yerde kalmıştı. Zar zor camiye getirilip musalla taşına yerleştirilen ölüyü imam yıkamak istememiş, yanaşmalardan yaşlı Hürrük Ağa tabancasını çekip imamın ayağının dibine üç el ateş etmiş, bunun üstüne titreyerek ölünün yanına giden imam, Ali Safa Bey'e birkaç maşrapa su döküp işi bitirivermişti. Namazı altı kişi kılmış, mezarlığa üç kişi gitmişti (Kemal, 2000b: 72).

Serinin dördüncü cildinde ise ince Memed'e yardım ve yataklık ettiği için Kırkgöz Ocağı'ndan Anacık Sultan'ın, karakolda gördüğü şiddet sonucunda ölümü gerçekleşir. Karakoldan alınan ölü bedeni Kırkgöz Ocağı'nın avlusuna taşınır:

Haberi duyan yörenin ileri gelenleri, ermişleri, pirleri, dedeleri, abdalları vb. gelip Anacık Sultan'ın huzurunda el bağladılar, kıyama durdular. Ve ak başörtülü, kara çatkı bağlamış, renk renk fistanlarıyla ortalığı bir renk cümbüşüne boğmuş kadınlar ölünün bulunduğu taşın yöresine halkalandılar. Yöreden duyan kadın kara çatkı bağlayıp, ak başörtülerini başlarına sararak, bayramlıklarını, düğünlüklerini giyinerek, 
incilerini, altınlarını, mercanlarını, göktaşı gerdanlıklarını, eski mezarlardan çıkmış boncuklarını, takılarını takarak ardı arkası kesilmeden geliyorlardı (Kemal, 2000c: 524).

Ağıda ilk olarak Hürü Ana başlamıştır. Onun sağ yanında soylu ağıtçı bey kızı Telli Hatun, solunda da Telli Hatun'un kız kardeşi hak aşığı, "türküleriyle, ağıtlarıyla taşı dile getiren, akarsuları durduran, ağaçları yürüten, dağları titreten" Hasibe Hatun durmaktadır. Hürü Ana önce ağıttan bir dörtlük söylemiş, halkalardaki bütün kadınlar hep bir ağızdan onu tekrarlamışlar, ardından da gene hep bir ağızdan ağlamışlardır (Kemal, 2000c: 525). Ağıtlar ölüye dair iyi şeyler söylenerek devam ederken:

Hürüce Ana ayağa kalktı, onunla birlikte halkadaki yüzlerce kadın da kalktı. Hürü Ana, Anacık Sultanın önüne geldi, el bağladı, boyun kırdı, ardından da eğildi, niyaza durdu, sonra da ölünün elini aldı üç kere öpüp başına götürdü. Ve yeniden, daha gür, daha başka bir sesle ağıdına başladı... Ve kadınların ağıtları ikindi üstüne kadar sürdü. Sonra ölüyü kokulu sabunlarla yudular, ipek kefene sardılar, ceviz ağacından tabuta koydular, tabutu eller üstünde taşıyarak karşıdaki, gece gündüz üstünden hiç ışık eksilmeyen, her zaman yalp yalp yanan çakmaktaşından doruğa yöneldiler... Doruktaki çakmaktaşı kayalığın içine ustalar apak bir mezar yapmışlardı. Anacık Sultanı getirdiler mezara indirdiler. Ferhat Hoca Kuran okudu. Mezardaki ölünün üstüne herkes elindeki çiçeği attı... (Kemal, 2000c: 526-527).

Aynı ciltte Yedikardeşler köyünden Mestan'ın öldürülmesinden sonra defin işlemleri şu şekilde yapılır:

...delikanlılar vardılar, Mestanın ölüsünü avludaki yontma, üstünde üzüm salkımları ve koç başı kabartması olan taşın üstüne yatırdılar. Köyün camisi, imamı yoktu, Ferhat Hoca yandaki pınardan abdest aldı. Ötekiler de abdest aldılar. Ferhat Hoca kollarını sıvadı, ölünün kanlı bedenini bir kalıp sabunla iyice yıkadı. Kurutup kefenlediler. Ölüyü bir salacaya koyup çırılçıplak bir yamaca götürüp çoktan kazılmış mezara, üstüne mersin dalları atarak gömdüler. Hoca, bir toprak mezarın üstüne, burada bütün mezarlar topraktı, oturdu, güzel sesiyle uzunca bir Kuran okudu. Cemaat önde, eşkıyalar arkada, köye geri geldiler. O gece, bütün evler ölü yemeği pişirmiş̧iler. Bütün köylüler ölü evinde bir araya gelerek yemek yediler (Kemal, 2000c: 574).

ince Memed roman serisinde Ferhat Hoca bir başka sosyal eşkıya karakteridir. Kendisine yapılan haksızlık neticesinde ince Memed'e katılmaya karar vermiş imam kökenli bir eşkıyadır. Nehir romanda, kendilerinin önem 
verdiği insanların ölümünden sonra Ferhat Hoca İslam dininin gereklerine uygun olarak ölünün gömülmesi sürecinde yardımcı olmuştur.

Yaşar Kemal'in çocukluk döneminden kesitler içeren ve bir ölçüde biyografisi niteliğindeki Kimsecik üçlüsünün, ikinci cildi Kale Kapısı'nda ìsmail Ağa üvey oğlu Salman tarafından camide namaz kıldığı bir anda bıçaklanarak öldürülmüştür. Cenaze merasiminde yerine getirilen defin ritüelleri romanda şöyle aktarıır:

Avluda büyük kazanlar kurulmuş, kaktüs ağılının dibinde iri bıçaklı adamlar koyunlar kesip yüzüyorlardı. Bu kazanlarda yemekler pişecekti. Köyün yaşlı kadınları, genç kızları kazanların yöresinde, avluya, hasırların üstüne serilmiş kilimlerin üstünde telaşla dolaşıyor, üstünde birer buğu bulutu kazanlara bulgur, pirinç, patates, doğranmış et boşaltıyorlar, tahta kepçelerle karıştırıyorlardı durmadan. Buğulu yemek kokuları dağılıyordu yöreye... Öğleye doğruydu ki köy, dağın, kalenin yamaçları ağzına kadar doldu. Köyde iğne atsan insandan yere düşmezdi. Büyük kazanlarda pişen yemekler önce konaktaki Beylere götürüldü. Konağın büyük odasına uzun bir kilim sofra serilmiş, sofranın üstüne geniş, sırma işleme, eski zamanlardan kalma pırıl pırıl bir sofra örtüsü atılmıştı. Örtünün üstüne yufka, altın sahanlar, kaşıklar, çatallar, altın işleme billur bardaklar konmuştu (Kemal, 1999b: 31-32).

Yemek faslı ikindiye kadar sürer. Bu süreçte ağıtçı kadınlar da gelmeye başlamıştı. Türkmen'in başağıtcısı Çukurova'da ünlü Telli Hatun görkemli atıyla gelir. Telli Hatun'un gedikten çığlık atarak görünüşü bütün konukları şaşırtır. Onu bütün köy erkeği kadını, kocası genci, konuğuyla karşılar (Kemal, 1999b: 34). ilyada'da örneklerine rastlandığı gibi meslekten ağlayıcı kadınlar ölü gömme törenlerinin daha bir dokunaklı olması için sözle bezenmiş ağıtlar yakarak, ölen kişilerin kahramanlıklarını, ölüm anlarını, sanki kendi başlarından geçmiş gibi anlatırlar (Yücel, 2007: 6). Romana dönecek olursak, ağıtçı kadınların sayısı artar, Zala Hatun, yanında on beş kadar ağıtçı kadınla Eşe Hatun, Zeynep Ana, Döne Karı, Hüsne Hatun, Yeşil Ana Hatun gibi çok sayıda tanınmış ağıtçı yetiştikleri yörenin kıyafetlerini giyinmiş ve alınlarına siyah çatkı bağlamış bir halde toplanırlar:

Önce Telli Hatun geldi ölünün sağına geçip oturdu, arkadan Yeşil Anşa Hatun geldi, onun yanına çöktü. Sonra arkasından öteki kadınlar geldiler ölünün yöresine fırdolayı oturdular. Büyük sofa kadınlarla ağzına kadar doldu. Beyaz başörtüler üst üsteydi. Önce Telli Hatun elindeki ak mendili sallayarak, bu mendil i̇smail Ağanındı, uzun bir çığlık koyverdi. Sonra oradaki bütün kadınlar çığlığa katılıp birden sustular. 
Her kadının elinde de İsmail Ağanın bir şeysi vardı, mendilleri, kuşağı, çorapları, gömlekleri, tabancaları, hançerleri, tespihleri, sigara ağızlıkları (Kemal, 1999b: 37).

Ağıt yakan kadınlar ölüyü överken, sağlığında insanlar arasındaki saygın konumundan, dostluğundan, güzelliğinden ve kardeşliğinden söz ederler. Toplumsal cinsiyet sosyolojisi açısından bakıldığında, geleneksel toplumlarda yas törenlerini düzenleme ve yürütme etkinliğinin kadınlar tarafından yapılmasının birçok sebebi sıralanabilir. Bunlara, kadına toplum tarafından duygusal bir kimlik inşa edilmesi ve duygularını dile getirme eyleminin kadına yakıştıııması ile kadının doğurganlık özelliğinden dolayı biyolojik olarak erkeğe ve daha sonra çocuğuna bağımlı bir varlık kabul edilmesi sebebiyle bu kişilerin ölümü üzerine psikolojik yönden daha derin bir deformasyona uğruyor olma ihtimalleri gösterilebilir. Sosyolojik yönüyle konuya eğildiğimizde ise Durkheim'in mekanik toplum/organik toplum ayrımı temelinde ele alındığında, ağıtların birincil ilişkilerin yoğun olduğu geleneksel (mekanik) toplumlarda yaygın olduğu söylenebilir. Ağıt yakma ve söyleme, geleneksel yaşam tarzının var olmaya devam ettiği topluluklar tarafından geleneğe büyük oranda bağlı kalınarak sürdürülmektedir. Toplumsal hafıza ağıtın aktarımında önemli bir yere sahiptir. Sözlü bir gelenek kabul edilen ağıt, yerel topluluklar tarafından yazıya aktarılmaya ihtiyaç duyulmadan, kaybolmadan var olmaya devam etmektedir. Bu özellik ağıt geleneğinin Anadolu'nun en güçlü sözlü kültürlerinden biri olmasından kaynaklanır (Tahtaişleyen, 2013: 19-133).

Romana dönecek olursak, ölünün suyu nar ağacının köşesinde bir büyük kazanda kaynarken, ak sakallı, kolları çevrenmiş beş tane hoca sabırla, kayalıklardan yana olan avlu duvarının dibine, taşlara oturtularak kurulmuş uzun masaya ismail Ağa'nın getirilip çırılçıplak konmasını beklemişlerdir. Az sonra gene bir kilimin içinde, delikanlılar uçlarından tutarak ölüyü getirir, tahtaların üstüne koyarlar. Ölünün belden aşağısına sırma işleme ipekli bir mavi havlu örtülmüştür. Hocanın bir elinde koskocaman pembe bir kalıp sabun vardır. Öteki hocalar büyük kulplu taslarla kazandan masaya su taşıyıp, ölünün üstüne dökmeye başlarlar. Eli sabunlu hoca bir yandan dua okur bir yandan da sabunlayarak, bol bol köpürterek Ismail Ağa'yı yıkar. Ölünün yıkanması, kefenlenmesi, sonra da salacaya uzatılıp omuzlara verilmesi tasvir edilmektedir. Tahta minarede ezan okunur. Birkaç dakika içinde ölü camiye götürülüp musalla taşının üstüne konur, ardından da namaza durulur. Cami kalabalığın ancak çok küçük bir parçasını almıştır. Namaz da çok az bir sürede biter. Mezarlık yakındır. Sa- 
laca camiden çıkarılıp, eller üstüne mezarlığa doğru götürülür (Kemal,1999b: 45-46). Cenaze töreni mezarlıktaki definle sürer:

Ölü mezara indirilirken ortalıkta çıt yoktu, az sonra birkaç imam birden gür sesleriyle Kuran okumaya başladılar. Ölü ak kefeniyle toprağa indirildikten sonra, kalın dayama ağaçlarını, bir ucunu dibe, bir ucunu da mezarın duvarına dayayarak, baştan ayağa sıralayıp, bu dayamaların üstüne de yeşil mersin dallarını döşediler. Mersin dallarının üstü birkaç kürek elden ele geçerek bir anda toprakla örtülüp, kocaman, uzun sarı bir yığın oluştu. Adamlar başları yerde ağır ağır mezarlıktan uzaklaşırken ortalıkta çıt yoktu, yalnız köyün içinden, konaktan daha kadınların ağıt sesleri geliyordu (Kemal, 1999b: 47).

Yaşar Kemal'in romanlarında cenaze merasimlerinde ağıtçı kadınlardan bir geleneği sürdürüyormuşçasına söz edilir. Çukurova Türkmenlerinde, kim olursa olsun, ağıt yakmak gelenek görenektir. Ölü önlerinde olmazsa, kadınlar ölünün giyitleri üstüne de, tıpkı ölü önlerindeymiş gibi ağıt yakarlar. Ölüye ağıt yakılır (Kemal, 2000b: 113-116-294).

Ayrıca ölüm olayından sonra sevdikleri tarafından kara başörtü bağlanır. Örneğin Yılanı Öldürseler'de, büyükana, oğlunun öldürülmesiyle kara başörtü bağlamıştır. Bu, kişinin yas tuttuğu anlamına gelmektedir. Bu süreç ağıtla birlikte gider. Diğer yandan Dağın Öte Yüzü’nde Taşbaş gibi köylünün kabul ettiği, gerçekliğin ötesine geçerek bir ermiş statüsü kazandırılanların ölü gömme törenlerinde farklılıklar gözlenebilmektedir. Köylünün zor koşullarda umudu olması nedeniyle, Taşbaş'ın ölümü intihar girişimiyle bile olsa köylünün nazarında bir olumsuzlama görmez.

\section{Sonuç}

Dünyanın hemen hemen her bölgesinde dinsel, sosyal-kültürel dinamikleriyle birlikte ölü gömme ile ilgili ritüeller bir gelenek halinde yapılmaktadır. Özellikle ölünün gömüldüğü toprak üzerinden toplumsal bütünleşme adına bir kutsal mekân oluşturulması sağlanırken, toplumda ölenler arasında sosyal yönden saygınlığı olanlara ise apayrı bir yer verildiği görülmektedir. Anadolu coğrafyası bu anlamda önemli bir deneyime sahiplik yapar. Bu durum edebi metinlerde de yerini almıştır. Toplumsal gerçeği birçok yönüyle yansıtan edebi metinler defin ritüellerine dair bilgiler içermektedir. Bu meyanda Yaşar Kemal, Çukurova bölgesi merkezde olmak üzere yapıtlarının geçtiği koşullarda yaşayan toplumların ölü gömme geleneklerine de yer vermiştir. Sosyal kültürel özelliklerin defin ritüelleriyle ele alındığı roman coğrafyasında, ağıt yakmanın ise günümüze kadar aktarılarak devam ettiği söylenebilir. Yaşar Kemal'in incelenen romanların- 
da, cenaze merasimlerinde ağıt yakanların kimler olduğu, bu kişilerin ağıt geleneğini sürdürme biçimleri, ağıt yakma tarzları ve sosyal-kültürel durumları ayrıntılı bir şekilde işlenmiştir. Bir çıkarım yapmak gerekirse, roman olaylarının geçtiği geleneksel/ataerkil toplumlarda, defin törenlerinde özellikle ağıt yakmak kadınlar aracılığıyla yerine getirilmektedir. Bu, başlı başına kadınların baskın olduğu defin ritüellerinde ağıt yakmayı yaşatılan önemli bir kültürel öge haline taşımıştır. Böylece Yaşar Kemal, romanlarının kültürel çerçevesini oluşturan Türkmen kültürünün, insan ölüsüne yaklaşımındaki insani duyarlıığı ağıtın evrensel sosyolojisine dikkat çekerek işlerken, edebiyat sosyolojisinde tartışılmasına büyük bir katkı sağlamaktadır (Şeker 2020: 301).

Sonuç olarak Yaşar Kemal'in romanlarında ölüye saygı felsefesinde, köklerini insana koşulsuz değer veren kültür ve sosyal yapıdan alarak cenaze merasimlerinde yapılan defin ritüelleri (ağıt, mezar yeri, cenaze yemeği, taziye, yas gibi) Anadolu kültür tarihinde toplumsal bellek oluşturmak adına önemli bir sosyal işlevi yerine getirmektedir. Antropolojik düşünce temelinde mezar odaklı bir kutsallıktan hareketle bakıldığında ise ölüm olayının karşısında toplumsal sistemin varlığını sürdürmesi için ritüel olarak anlamlandırılan eylemlerden destek alındığını belirtmek gerekir.

\section{Kaynakça}

Aslan, Şükrü (2017). "Sürgünde Ölüm”. MSGSÜ Sosyal Bilimler Dergisi, I/16: $240-250$.

Becker, Ernest (2013). Ölümü inkar. Çev. Arzu Tüfekçi. İstanbul: İz Yayıncılık.

Bauman, Zygmunt (2012). Ölümlülük, Ölümsüzlük ve Diğer Hayat Stratejileri. Çev. Nurgül Demirdöven. İstanbul: Ayrıntı Yayınları.

Can, Berivan (2015). "Batman Ezidîlerinin Defin Pratikleri Üzerine Etnografik Değerlendirmeler”. Antropoloji, 29: 163-179.

Durkheim, Emile (2010). Dinsel Yaşamın ilk Biçimleri. Çev. Özer Ozankaya. istanbul: Cem Yayınevi.

Eriksen, T. Hylland (2019). Küçük Yerler, Büyük Meseleler. Sosyal ve Kültürel Antropoloji. Çev. Erkan Koca. Ankara: Atıf Yayınları.

Freud, Sigmund (1995). Uygarlık Din ve Toplum. Çev. Selçuk Budak. Ankara: Öteki Yayınevi.

Garnett, M. J. Lucy (2009). Türkiye'nin Kadınları ve Folklor Özellikleri. Çev. Nurettin Elhüseyni. İstanbul: Oğlak Yayınları. 
Güvenç, Bozkurt (1991). Insan ve Kültür. İstanbul: Remzi Kitabevi.

Homeros (2003). Odysseia. Çev. Azra Erhat ve A. Kadir. İstanbul: Can Yayınları.

Homeros (2019). ilyada. Çev. Azra Erhat ve A. Kadir. İstanbul: Türkiye iş̧ Bankası Kültür Yayınları.

Kemal, Yaşar (1998). Demirciler Çarşısı Cinayeti-Akçasazın Ağaları 1. istanbul: Adam Yayınları.

Kemal, Yaşar (1999a). Yusufçuk Yusuf-Akçasazın Ağaları 2. İstanbul: Adam Yayınları.

Kemal, Yaşar (1999b). Kale Kapısı-Kimsecik 1. İstanbul: Adam Yayınları.

Kemal, Yaşar (2000a). Ölmez Otu-Dağın Öte Yüzü 3. İstanbul: Adam Yayınları.

Kemal, Yaşar (2000b). Ince Memed 3. İstanbul: Adam Yayınları.

Kemal, Yaşar (2000c). Ince Memed 4. İstanbul: Adam Yayınları.

Kemal, Yaşar (2001). Binboğalar Efsanesi. İstanbul: Adam Yayınları.

Kızılçelik, Sezgin (2000). Sosyoloji Yazıları. Ankara: Anı Yayınları.

Maden, Sait (2018). Gılgamış Destanı. Çev. Sait Maden. İstanbul: Türkiye İş Bankası Kültür Yayınları.

Seale, Clive (2012). "Yaşam/Ölüm". Temel Sosyolojik Dikotomiler. Ed. Chris Jenks, Çev. Ed. ìnsan Çapçıoğlu, Böl. Çev. Rabia Çetin ve Ayşe Nur Güdekli. Ankara: Birleşik Yayınevi, 447-468.

Şeker, Aziz (2020). Edebiyat ve Toplumsal Cinsiyet. Ankara: Gece Kitaplığı. Tahtaişleyen, Nihan (2013). Anadolu Ağıt Geleneğinin Özellikleri ve Kültürel Süreklilikteki Rolü. Yüksek Lisans Tezi. İstanbul: MSGSU Sosyal Bilimler Enstitüsü.

Tahtaişleyen, Nihan (2017). "Ağıtların Edebî Özellikleri Üzerine Bir Literatür ve Veri Analizi”. MSGSÜ Sosyal Bilimler Dergisi, 1/16: 222-239.

Timur, Taner (2002). Osmanlı-Türk Romanında Tarih, Toplum ve Kimlik. Ankara: İmge Yayınları.

Tryjarski, Edward (2012). Türkler ve Ölüm: Geçmişten Bugüne Türklerde Ölüm Kültürü. Çev. Hafize Er. İstanbul: Pinhan Yayıncılık.

Yücel, Müslüm (2007). Edebiyatta Ölüm ve intihar. İstanbul: Agora Kitaplığı. 